\title{
15
}

\section{Whispers and Sighs: The Unwritten Challenges of Service-Learning}

\author{
Rona J. Karasik
}

St. Cloud State University

Documentation of the benefits of service-learning abound, and published case studies of successful service-learning programs may be found for a variety of disciplines. Faculty new to service-learning, however, are likely to find themselves facing a variety of unexpected challenges. While these challenges are neither insurmountable nor unknown to experienced service-learning practitioners, they can make starting a service-learning program remarkably time-consuming and unnecessarily frustrating. Unfortunately, pitfalls and program flops are rarely published. This chapter forewarns some of the challenges associated with service-learning and offers realistic approaches to dealing with them successfully.

\section{INTRODUCTION}

While service-learning has been around since the 1960 s and perhaps even earlier (Stanton, Giles, \& Cruz, 1999), this unique form of experiential education is now rapidly taking center stage on many campuses (Colby, Ehrlich, Beaumont \& Stephens, 2003). Numerous studies have documented service-learning benefits for students, ranging from personal and interpersonal development, to civic engagement and enhanced critical thinking skills (Eyler \& Giles, 1999). In turn, communities can gain needed assistance and a renewed appreciation of the skills and talents of local students (Westacott \& Hegeman, 1996). Similarly, service-learning has the potential to enhance a faculty member's service and teaching, as well as research (Ward, 1998). 
Harvesting the many benefits of service-learning requires careful planning, however, and faculty new to service-learning may find themselves facing a variety of unexpected challenges. While these challenges are neither insurmountable nor unknown to experienced service-learning practitioners, they can make starting a service-learning program remarkably time-consuming and unnecessarily frustrating. Unfortunately, pitfalls and program flops are rarely published. Rather, they are heard as whispers and sighs among faculty in between classes, on the way to meetings, and over lunch at professional conferences. This chapter will document some of these challenges and offer realistic coping strategies. As the old saying goes, "forewarned is forearmed."

\section{What Is Service-LearNing?}

One of the first backroom whispers to be heard is "What really is service-learning?" Often service-learning is confused with other community-based experiential endeavors, such as volunteer work, community service, field work, and internships. Like these other forms of experiential learning, service-learning seeks to engage students in hands-on activities designed to provide opportunities for learning and development (Flannery \& Ward, 1999; Howard, 1993; 1998). Service-learning is, however, a unique pedagogical approach which seeks to balance equally the learning needs of students with the service needs of the community (Furco, 1996). Designed with different goals in mind, other forms of community-based experiential learning tends to be focused more substantially on either student learning (e.g., internships and field work) or on community outcomes (e.g., volunteerism and community service) (Furco, 1996; Jacoby, 1996; Karasik \& Berke, 2001).

While many sources are available for a more complete discussion of the principles of service-learning (Furco, 1996; Heffernan, 2001; Howard, 1993, 1998; Rhoads \& Howard, 1998; Stanton, Giles \& Cruz, 1999), it is helpful to ourline some of the essential elements. This includes, on the service side, having students provide meaningful service that meets a need or goal that has been identified by the community. On the learning side, it is necessary to have students complete assignments designed to help them reflect on their scrvice work as it relates to the learning objectives of the course (Weigert, 1998).

Service-learning is a practice that can take many forms, depending upon the learning goals of the students and the current needs of the community. For example, students in a class studying youth literacy might serve as elementary school reading tutors (Rice \& Pollack, 2000), while classes in gerontology might find themselves learning about aging and older adults as they participate in intergenerational recreational and chore activities (e.g., grocery shopping) 
(Karasik \& Berke, 2001; Westacotr \& Hegeman, 1996). Matching the appropriate community need with the pedagogical objectives of a particular course is one of the first challenges of service-learning.

\section{Challange 1: Pedagogy}

Discussions of the pedagogical challenges of service-learning can fill many volumes in their own right (Heffernan, 2001; Jacoby \& Associates, 1996; Rhoads \& Howard, 1998). What follows is a brief overview of the key pedagogical concerns faculty face in implementing a new service-learning program.

\section{Getting Started}

Because service-learning can take so many forms, it is easy to become overwhelmed (or underwhelmed) with ideas for how to get started. Several good resources exist that can help. For example, Heffernan's (2001) Fundamentals of Service-Learning Course Construction describes the six basic models for servicelearning ranging from "pure" service-learning to discipline and problem-based models to ways of incorporating service-learning into specialized capstone courses, service internships, and community-based action research. The text also includes information on the basics of service-learning implementation, including sample syllabi. Heffernan's text is produced by Campus Compact, "a national coalition of... college and university presidents devoted to the civic purposes of higher education" (Campus Compact, 2000, p.1). Additional Campus Compact resources are available in their Introduction to Service-Learning Toolkit (Campus Compact, 2000), and on their web site: www.compact.org

Best practice articles from within one's own field are another good place to start, since approaches to service-learning vary by discipline (Howard, 1993; Karasik, Maddox, \& Wallingford, in press). The American Association for Higher Education's Series on Service-Learning in the Disciplines is an excellent source in this regard (Zlotkowski, 1996). It is important to keep in mind, however, that best practice articles tend to focus on what works rather than on what does not. Colleagues experimenting with service-learning in your discipline, as well as faculty from other fields, are another excellent resource. They are the most likely to give an accounting not only of what worked but also of what did not.

\section{Meeting Course Objectives}

By definition, the work students perform in service-learning must be linked to the objecrives of the course. Like any other course assignment, careful consideration must be given to the question "What do I want students to learn from 
this?" While this question may seem fairly straightforward, it does require that the objectives of the course be made explicit. Rather than trying to fit a particular activity to an objective, far more productive is to start with the objectives, then envision ways of accomplishing them. Remembering that servicelearning may or may not be the best pedagogical approach to a particular goal is important. Pressure to "do" service-learning should not be the primary reason for trying it.

On the other hand, there is a great deal of learning that can be accomplished through service-learning (Eyler \& Giles, 1999; McEwen, 1996). This learning may be primarily content based (Morton, 1996), or more likely, it will incorporate higher-order outcomes such as critical thinking, personal and interpersonal development, and perspective transformation (Eyler \& Giles, 1999). An important challenge here stems from our limited ability to control the types of experiences from which our students are learning. Clearly, not all experiences are likely to produce positive learning outcomes. For example, Erickson and O'Conner (2000) raised the concern that some service contact experiences may be more likely to promote rather than reduce student prejudices. Similarly, Paul Loeb, author of Soul of a Citizen (1999) and Generations at the Crossroads (1994), recounted a story of a student who missed the forest for the trees when, while raving about his experience at a homeless shelter, expressed hope that the shelter would still be around for his grandchildren to work in. While few have publicly documented these negative outcomes, careful integration of students' service experiences into the course content is clearly vital. Critical reflection is a key component to achicving such integration.

\section{Reflection}

An underlying premise of service-learning is that having students "do" service is not enough to cultivate effective learning. Rather, students must be helped to integrate their experiences with theory (Bringle \& Hatcher, 1999). There are many ways to help students reflect on what they are learning, ranging from group discussions (large and small) and journals (including weekly reflection questions and e-journals), to directed readings and analytic papers (Bringle \& Hatcher, 1999; Cooper, 1998; Dunlap, 1998; Kottkamp, 1990).

The challenge for many faculty is selecting reflection formats that match their teaching style. In-class discussions require faculty flexibility to seize upon the elusive teachable moment. While the concept of reciprocity may not have been on the class schedule for that day, a student's complaint about being overwhelmed by cookies from her elderly community shopping partner requires a 
shift in plans. Discussions of this kind can be highly satisfying and effective for students, although constant shifts of this nature can play havoc with class schedules.

Written journals can provide faculty with more time for reflecting on the reflection, but may lose the immediacy of the moment. Lengthy journals may also be less practical for faculty with heavy grading loads. Many faculty find hybrid approaches of reflection to be satisfactory, perhaps by scheduling regular in-class discussions along with weekly open-ended written reflection questions to be completed outside of class (Karasik \& Berke, 2001).

\section{How to Cover Everything}

Another unwritten but often whispered challenge for faculty is that it is almost impossible to cover everything - whether you include service-learning or not. This reality can make anyone skittish about adding to an already overloaded course. With this mind-set, service-learning could never happen. Rather, service-learning must be seen as integral to the course (Howard, 1998).

Designing a service-learning component requires rethinking a course and prioritizing important elements. Service-learning opportunities may then be used, where appropriate, to illustrate key concepts and ideas. Service-learning should be seen, thus, as a core educational tool in the same way that textbooks, lectures, and class discussions are viewed. Use of a particular approach will depend upon the outcomes desired. In many cases, service-learning is an effective way to convey course information (e.g., about diverse populations, civic responsibility, and real-world practice).

\section{Designing a Service-Learning Component}

Once one decides on service-learning as an approach, the ever-present challenges of defining the details remain. The answer to many questions such as "Where will students be placed?" and "What exactly will they be doing?" will depend upon both the learning goals of the class and the needs of the community. Other basic considerations include "How many hours must students complete?" and "Will the service-learning assignment be optional or mandatory?" These questions are solved often by trial and error. Some faculty find that a one-time project (e.g., a day-long community event) is sufficient to engage students in community concerns, while many others ope for semester-long service placements requiring 20 to 30 hours or more on site in the community.

Similarly, practitioners do not agree as to whether service-learning should be optional or mandatory (Karasik, in press). Arguments for mandatory participation include having all students gain the potential benefits of service- 
learning. A mandatory approach is not, however, without risks. For example, one must consider the responsibility of the university to a community partner for possible negative outcomes if an unwilling student feels forced into participating. Potential problems may range from students not showing up to being unprepared, uncooperative, or even disruptive when they do. Such negative behavior can mar the service-learning experience for all involved and place student-community partnerships at risk. While empirical data on negative outcomes for community partners are limited, anecdotal data on individual "bad apple" problems may be found (Karasik, in press).

Alternative approaches to requiring service-learning of all students is to offer service-learning as an optional assignment. Several optional models are available, including making service-learning available for an additional course credit (a fourth credit option) or offering service-learning as part of a partnered course such as a related internship (Heffernan, 2001). A third approach is to offer alternative nonservice assignments within the class-such as term papers or other intensive assignments. The challenge is, of course, to create and evaluate assignments of equivalent scale and benefit.

\section{Assessment and Evaluation of Student Learning}

Measuring the outcomes of service-learning poses yet another series of challenges. In many ways, the problem is no different than measuring outcomes of other pedagogical approaches-which is to say that it is a significant challenge (Driscoll, Holland, Gelmon, \& Kerrigan, 1996; Gelmon, Holland, Driscoll, Spring, \& Kerrigan, 2001). Studies suggest that students like service-learning and believe they get more out of it than traditional classes, although gains in factual knowledge are fairly equivalent (Eyler \& Giles, 1999). Two important questions to consider are thus "Do students gain in other areas beyond factual knowledge" and "How do you measure such gains?" While traditional evaluation modes such as examinations are helpful in measuring factual knowledge, they are rarely adequate in getting at touted service-learning benefits such as interpersonal development, civic engagement, and enhanced critical thinking. Other evaluative approaches that have been suggested include using pre/post assessments of learning goals (e.g., to determine students' perceptions), formal written evaluations by students, data regarding if and for how long students continue service beyond course requirements, and data on students' selection of majors and occupations following service-learning.

While the above measures can help in gauging the impact of service-learning on overall student learning, the question remains of how one can best measure individual student performance. For example, "Should service-learning be 
graded, and if so, how?" Howard (1993) stressed the importance of grading the learning and not the service, using the example that in a traditional history class you would test students on the knowledge they had gained from an assigned reading, not on their ability to read the assignment. If participating in servicelearning is equivalent to doing the assigned reading, then assignments such as final papers where students reflect on their service experience and integrate it with course concepts might be the basis for a grade. Students do not always appreciate, however, this approach to evaluation. It is not uncommon for a student to reflect on a less than exemplary grade by saying "but I really liked the service-learning" or "but I completed my required hours" or "I worked really hard at the service part." These comments reflect the increased commitment students feel to classes with service-learning, as well as the importance of making grading procedures clear from the outset.

\section{Assessment and Evaluation: Impact on the Community}

Assessing the impact of service-learning on the community is no less important, nor less challenging. Many components require evaluation, ranging from each constituencies' satisfaction with the university-community partnership to the actual impact of the service on the community. With regard to satisfaction with the partnership, Gelmon et al. (2001) suggested using indicators such as partners' "perception of mutuality and reciprocity," "responsiveness to concerns," and "willingness to provide feedback" (p. 92) via interviews, surveys, and focus groups. While such formal measures are helpful, it is important to be sensitive to informal indicators of satisfaction (e.g., praise) or lack thereof (e.g., frustration or lack of communication) as well.

The ease with which one can measure the impact of students' service on the community depends upon how the goals of service-learning have been identified. While the task of defining mutually beneficial goals will be discussed more fully in the following section, Gelmon et al. (2001) offers several broad indicators of community impact such as the "types of services provided," "number of clients served," "number of students involved," "variety of activities offered," "impact on resource utilization through services provided by faculty/students," and "impact on community issues" (p. 92), which are useful to consider here.

\section{Challenge 2: The Community}

Community is a key component of service-learning. Without community support, service-learning could not exist. Gaining community support, however, can be a complex task. While many community groups welcome student 
participation, others do not. More than one faculty member has been taken by surprise by a potential community partner's resistance to their advances. Some have even given up their aspirations for service-learning because they have been unable to gain entry into the community. To increase the ease with which access is granted, one needs to consider the overall relation between universities and the surrounding community.

\section{The Ivory Tower}

Despite efforts to the contrary, the ivory tower image of universities is very much alive. Similarly, while some communities view local universities as economic and educational resources, many also see universities as conspicuous consumers of land, parking, and law enforcement. Post-homecoming images of drunken, out-of-control college students do little to diminish this unfortunate stereotype. Remarkably, positive stories describing student and faculty contributions to the community (e.g., as employees, volunteers, taxpayers, and supporters of the local economy) do not make for interesting news. While service-learning and other forms of community interaction could be a way to repair a university's image problem, one must address the essential questions of "How and where does one begin?"

\section{Reaching Out}

A first step in gaining community support is to identify potential community partners (local agencies, community groups, etc.) that may have an interest in working jointly on a service-learning project. More often than not this will require some fact finding to know who does what in a particular community. Becoming informed suggests you have a genuine interest in the local community. It does not, however, guarantee that the community will have an interest in you.

The next step is to make a connection-networking is not just for the business world. Personal interaction builds trust. As simple as it may sound, meeting someone off campus can go a long way to dispelling the aloof faculty stereotype. Similarly, inviting a potential partner to class as a guest speaker might help to create a connection both to faculty and students, while also acknowledging that the community member has valuable expertise.

Communication is also a key component. Open discussion of potential concerns is important. In some cases, building trust might be an issue. In other cases, concerns may exist about limited resources, liability, staffing, time constraints, exploitation of clients, or poor interactions with the university, faculty, or students in the past. Many such issues may be resolved by examining alternative approaches. For example, if an agency is concerned about being 
able to handle too many students at one time, perhaps additional community sites may be added to ease the burden. This solution may be easier to do in larger areas where the concentration of appropriate community opportunities is greater. In some cases, community concerns may be so great that developing a service-learning partnership elsewhere may be necessary, leaving the possibility of collaboration with the initial partner open for the future.

\section{Building a Partnership}

By definition, communities need to be collaborative partners in service-learning. Hence, it is necessary to approach a community agency or organization by asking what it is that they see as a need students could fulfill. All too often, the temptation is to approach potential community partners with notions of how students and the university can fix the community. While the desire to help is commendable, unwanted help is likely to widen the town-gown divide. Gugerty and Swezey (1996) warned educators against perpetuating the notions that "there exists superior and deficient cultures" (p. 95) and "that faculty know better how to solve local problems than ... those who live in [the] communities" (p. 96). For service-learning to work, educators and communities must work together as equal partners to develop projects that serve the needs of the students and the greater community (Karasik \& Berke, 2001).

\section{Mutually Beneficial Tasks}

In order to identify mutually beneficial tasks, each constituency first must understand their own needs. For faculty, this step means carefully reviewing the curriculum to define concretely the objectives of the course. While this task may seem too simple to mention, more than one faculty member has been hard pressed to articulate the exact knowledge and skills they expect their students to take away from the course. Faculty must then be able to express clearly these course objectives and their goals for service-learning to their community partners.

Community partners, on the other hand, need to be realistic about what services students can provide for them and what they can provide for students. Students are apprentices rather than experts. Good communication between the partners as to what students will (and will not) do is important. Other considerations (e.g., expectations, supervision, orientation, liability, background checks, timelines, division of labor, and evaluation) should be discussed and perhaps even put into writing before presenting the service-learning project to the students. Even then, a means for ongoing communication throughout the service-learning process is necessary to maintain a viable, mutually beneficial relationship. 


\section{Challenge 3: The Students}

Like the community, students are a key component of service-learning. Without the students, service-learning would not exist. In fact, enhancing student learning is one of the primary reasons many faculty get involved in servicelearning. In turn, students like service-learning - at least they say they do after it is over. Several studies have reported that the vast majority of students participating in service-learning perceived significant benefits from doing so (Chapman \& Morley, 1999; Hessmiller \& Brown, 1995; Karasik et al., in press; McKenna \& Rizzo, 1999). Of course, the challenge for faculty is getring students to participate in service-learning so that they may experience its many benefits.

\section{"You Want Me to What?"}

While many students welcome service-learning opportunities with enthusiasm, other students greet the prospect of service-learning with more reticence. As one student so aptly put it during a service-learning introduction: "You want me to what? You have got to be kidding!" Even if students do not openly voice this concern, one would be wise to be prepared for such a reaction. Understanding the source of a student's resistance is the first step to countering it.

For some students, resistance comes from being asked to do something new or different. The unknown can spark numerous questions, such as "What will be expected of me?" "Who are the people I will be working with?" "Is this something I can do well?" and the ever popular "How much time and effort will I have to put into this?" It is helpful to be ready for such concerns by preparing a detailed introduction to the service-learning project. This may be done in a variety of ways, including in-class discussions, instructions in the course syllabus, and through various handouts that students can refer to after the initial shock is over. In fact, a multi-pronged approach spread out over the first week of class is probably best-beginning with a brief discussion of what service-learning is, who will be served by the work, what types of tasks the class will be doing, and what the instructor's expectations for the students are. By spreading out the discussions, students have time to think about the project and to formulate their questions.

It is also helpful to make the unknown known by having students who have previously done service-learning (either from the current class or a previous class) give "testimony" to the benefits of service-learning. Having servicelearning "survivors" promore the experience is amazingly effective in getting new students on board. Introducing the community partners in class can also help to alleviate some of the fear that comes with exploring new territory. 
However, not all of the student resistance comes from encountering a new learning opportunity. A more challenging problem stems from student concerns about the amount of time service-learning requires. Karasik (in press) found that while a majority of students elected to participate in an optional service-learning program, of those who did not, time was their main concern, with students citing other school, family, and work commitments as insurmountable barriers to putting in service-learning hours. Transportation and distance to community sites emerged as related concerns. Suggested strategies for helping students make time for service-learning included:

- Requiring service-learning as a mandatory part of the course (an approach with a number of pros and cons)

- Offering a wide range of service opportunities to meet individual scheduling and transportation needs

- Offering "behind the scenes" type positions (e.g., project manager, project historian)

- Considering offering alternative, non-service-learning assignment options (Karasik, in press)

\section{One Size Does Not Fit All}

In addition to the possibility of student resistance to service-learning, it is important to remember that different types of service-learning approaches will work better with different groups of students. While tailoring programs to individual students can be difficult, it is helpful to consider differences in students' learning styles, backgrounds, and developmental stages (McEwen, 1996). Students who are new to higher education, for example, and those without any experience in the field may be less confident about approaching individual community agencies. Bringing community partners into the class as part of the project introduction is thus particularly important for this group. Introductory students may also require more supervision of their service-learning experiences both by the faculty and community partners (Karasik et al., in press).

On the other hand, upper-level and graduate students, as well as students with significant background in the field, may require a less hands-on approach. Experienced students may prefer to seek out their own service experiences which complement or possibly contrast their current or future employment areas. These students may also be more inclined to select service projects requiring greater initiative and preparation such as working with an 
agency to design a new service or to lead a new community program (Karasik et al., in press).

\section{Follow-Through}

Once students are suitably enticed to do service-learning, follow-through becomes an additional challenge. While ensuring that students complete their assignments satisfactorily is not a new concern of faculty, the stakes are raised when there are others relying on the students' work. As part of the collaborative process described earlier, faculty and community partners need to discuss contingencies ahead of time. If attainable, students will tend to rise to the expectations set out for them. Students failing to show up when expected or not completing promised tasks can, however, damage the collaborative relationship. Thus, preventative measures such as spelling out expectations and consequences during the orientation phase are essential, as is regular communication with community partners to gauge their satisfaction and concerns.

Similarly, checking in regularly with the students via the reflection process is necessary to make sure they are actively engaged and satisfied with their experiences. In addition to helping students make connections between their service work and course content, faculty must also ensure that the students are being provided with tasks that afford them good learning opportunities. Finding at mid-semester or later that students are either overwhelmed by their placements or discouraged at being relegated to the sidelines can be quite disheartening. Worse yet is finding students who have failed even to begin their service experiences because of procrastination or an inability to connect with the community partners.

Even when things are going smoothly, faculty should be prepared to handle the inevitable sticky assessment issues, such as what to do when a student wants to "drop out" of a service experience or how to grade a student who has not completed the requisite hours by the end of the semester. A stickier issue comes from the unfortunate fact that service-learning is not immune to cheating, with more than one student having "fudged" hours on their timesheets. While such eventualities are an unfortunate part of academia, here again prevention is the best policy.

\section{Challenge 4: The University}

Colleges and universities play an inceresting role in service-learning. Service is prominent in many institutions' mission statements, although there is considerable variability in exactly what is meant by this term (Ward, 1998). Certainly, universities stand to benefit when service-learning enhances both student 
learning and community relations. Alternatively, institutions incur some risk of reputation and possible liability should a university-community collaboration go awry. Thus it would seem that universities have a vested interest in the success of local service-learning endeavors. To that end, there are many ways a university can support service-learning. Not surprisingly, there are also many ways for it to impede the process.

\section{Campus Resources}

The first challenge of finding institutional support for service-learning is knowing where to look. Many campuses have service-learning coordinators, and perhaps even offices devoted to service-learning, volunteer services, faculty development, or other similar endeavors. While the function of such offices will vary from institution to institution, they are typically a good place to begin to gather resources and ideas. They may also be a good place to network with other faculty doing service-learning. For campuses without such services, seeking out other service-learning faculty via more informal avenues such as email and word of mouth can be helpful.

University grant assistance offices are another potential resource, particularly if you are interested in securing financial support for developing or expanding a service-learning program. While money has been tight in the past, service-learning is currently one of the hot funding buzz words, along with civic engagement and other service-related teaching approaches. A challenge with securing outside resources, however, is being careful to develop programs that are sustainable after the initial funding period. Programs that require ongoing external monetary support are going to be much more difficult to maintain over the long run.

In addition to financial support, there may also be opportunities to secure additional time to develop and administer service-learning. Such opportunities (which often come under the guise of names such as "scholarship," "reassignment time," and "course buyout") typically are best pursued through one's immediate supervisor. As with financial support, it is helpful to consider the sustainability of a particular service-learning program should such additional time become unavailable in the future.

\section{Faculty Development}

Another way an institution can support service-learning is by recognizing it as a valuable tool. Many institutions of higher education view research as their most important priority, leaving faculty with little time to prepare unique classroom experiences. Similarly, service-learning faculty may encounter peers 
unfamiliar with the approach who view service-learning as lacking in academic rigor. In a rare volume directed at explaining service-learning to university administrators, Jacoby and Associates (1996) offered suggestions for how institutions can enhance the sustainability of service-learning programs by accounting for the needs of the university, faculty, and community as well as the students. For example, Rue (1996) highlighted the importance of having administration take service-learning "seriously in tenure and promotion decisions" (p. 261). Faculty wishing to initiate or strengthen support for service-learning at their institution might consider finding a way for this book to reach the hands of their administrators.

\section{The Brick Wall}

Despite the good intentions of many institutions, there may be times when faculty wonder whose side the university is on. As is the nature of most institutions, change (and the spread of new ideas) happens slowly. While servicelearning is currently a hot topic around many campuses, one should note that less than 10 years ago getring funding or support for such endeavors was diffcult. Persistence does pay off. Even so, be prepared for the inevitable "you can't do that here" from offices where one might have expected support. For instance, while local academic administrators may be enamored with students' efforts to build a community playground for children of all abilities, the institution's business office may be less than receptive to helping these students find a way to accept donations for a playground that will not be sited directly on the university campus.

Similarly frustrating challenges have been experienced by faculty attempting to schedule service-learning classes outside of traditional time slots, as well as those secking to have students access campus resources typically reserved for faculty and administration (e.g., the services of university grant offices). While the specific nature of the challenges will vary by institution and service-learning project, the resulting experience of exasperation is universal. Perseverance, persistence, and creativity are key elements to survival when you run up against a brick wall. Of course, a little spin never hurts either with such experiences providing teachable moment material for faculty and students alike.

\section{Challenge 5: The Faculty Role}

The final set of service-learning challenges stems from within the faculty members themselves. Faculty are the essential element in designing and implementing service-learning programs. Ultimately, faculty must decide if service-learning is the right approach for their courses. They are also in charge of 
seeing that the challenges of designing and implementing a sound servicelearning program are addressed.

\section{What Am I Getting Myself Into?}

There are many self-evaluative aspects faculty should consider before beginning service-learning. For example, taking on a new teaching approach requires both time and energy-commodities that are in short supply for many faculty. The good news is that service-learning does become easier with experience. The reality is, however, that maintaining an effective service-learning program requires the same continued vigilance as other teaching approaches.

Working collaboratively with the community can also pose unique challenges for faculty, as it places them outside their traditional university roles. Community meetings may become a way of life for faculty sponsoring servicelearning programs, and many a lesson plan has been scrapped at the last minute when a unique service experience is brought to the classroom. On the other hand, class discussions may never be so lively or well informed.

\section{JUST REWARDS}

With good reason, the majority of literature touts the benefits of service-learning. Despite the many challenges of service-learning, the rewards are signifcant. For students, it is a way to learn by doing. For the community, it is a way to tap into the many talents students can provide. For the university, it is a way to improve community relations. For faculty, it is a way to connect on different levels with students, the community, teaching, and their chosen field. While those who do service-learning may grumble in the hallways and over lunch about the problems they face, most practitioners stay on the front lines. Their dedication speaks volumes. For all its challenges, when done properly, service-learning works.

\section{REFERENCES}

Bringle, R., \& Hatcher, J. (1999). Reflection in service learning: Making meaning of experience. Educational Horizons, 774), 179-185.

Campus Compact. (2000). Introduction to service-learning toolkit: Readings and resources for faculty. Providence, RJ: Author.

Chapman, J., \& Morley, R. (1999). Collegiate service-learning: Motives underlying voluntcerism and satisfaction with volunteer service. Journal of Prevention and Intervention in the Community, 18(1/2), 19-33. 
Colby, A., Ehrlich, T., Beaumont, E., \& Stephens, J. (2003). Educating citizens: Preparing America's undergraduates for lives of moral and civic responsibility. San Francisco, CA: Jossey-Bass.

Cooper, D. (1998). Reading, writing, and reflection. In R. A. Rhoads \& J. Howard (Eds.), Academic service learning: $A$ pedagogy of action and reflection (pp. 47-56). San Francisco, CA: JosseyBass.

Driscoll, A., Holland, B., Gelmon, S., \& Kerrigan, S. (1996). An assessment model for service-learning: Comprehensive case studies of impact on faculty, students, community, and institution. Michigan Journal of Community Service Learning. 3, 66-71.

Dunlap, M. (1998). Methods of supporting students' critical reflection in courses incorporating service-learning. Teaching of Psychologx, 25(3), 208-210.

Erickson, J., \& O'Conner, S. (2000). Service-learning: Does it promote or reduce prejudice? In C. O'Grady (Ed.), Integrating service learning and multicultural education in colleges and universities (pp. 59-70). Mahwah, NJ: Lawrence Erlbaum.

Eyler, J., \& Giles, D. (1999). Where's the learning in service-learning? San Francisco, CA: Jossey-Bass.

Flannery, D., \& Ward, K. (1999). Service learning: A vehicle for developing cultural competence in health education. American Journal of Health Behavior, 23(5), 323-331.

Furco, A. (1996). Service-learning: A balanced approach to experiential education. Expanding boundaries: Serving and learning. Washington, DC: Corporation for National Service.

Gelmon, S., Holland, B., Driscoll, A., Spring, A., \& Kerrigan, S. (2001). Assessing service-learning and civic engagement: Principles and techmiques. Providence, RI: Campus Compact.

Gugerry, C., \& Swezey, E. (1996). Developing campus-community relationships, In B. Jacoby \& Associates (Eds.), Service-learning in higher education: Concepts and practices (pp. 92-108). San Francisco, CA: Jossey-Bass.

Heffernan, K. (2001). Fundamentals of service-learning course construction. Providence, RI: Campus Compact.

Hessmiller, J., \& Brown, K. (1995). Learning to acr: Scrvice-learning integrates theory and practice. In J. Eby (Ed.). Service-learning: Linking academics and the community (pp. 213-220). Grantham, PA: Pennsylvania Campus Compact. 
Howard, J. (1998). Academic service learning: A counternormative pedagogy. In R. A. Rhoads \& J. Howard (Eds.), Academic service learning: A pedagogy of action and reflection (pp. 21-29). San Francisco, CA: Jossey-Bass.

Howard, J. (Ed.). (1993). Praxis I: A faculty casebook on community service learning. Ann Arbor, MI: OCSL Press.

Jacoby, B. (1996). Service-learning in today's higher education. In B. Jacoby \& Associates (Eds.), Service-learning in higher education: Concepts and practices (pp. 3-25). San Francisco, CA: Jossey-Bass.

Jacoby, B., \& Associates. (Eds.). (1996). Service-learning in higher education: Concepts and practices. San Francisco, CA: Jossey-Bass.

Karasik, R. (in press). Breaking the time barrier: Helping students "find the time" to do intergenerational service-learning. Gerontology o Geriatrics Education.

Karasik, R., \& Berke, D. (2001). Classroom and community: Experiential education in family studies and gerontology. Journal of Teaching in Marriage and Family: Innovations in Family Science Education, 1(4), 13-38.

Karasik, R., Maddox, M., \& Wallingford, M. (in press). Intergenerational servicelearning across levels and disciplines: "One size (does not) fit all." Gerontology o Geriatrics Education.

Kottkamp, R. (1990). Means for facilitating reflection. Education and Urban Societs, 22, 182-203.

Loeb, P. (1994). Generations at the crossroads: Apathy and action on the American campus. New Brunswick, NJ: Rutgers University.

Loeb, P. (1999). Soul of a citizen: Living with conviction in a cynical time. New York, NY: St. Martin's Griffin.

McEwen, M. (1996). Enhancing student learning and development through servicelearning. In B. Jacoby \& Associates (Eds.), Service-learning in higher education: Concepts and practices (pp. 53-91). San Francisco, CA: Jossey-Bass.

McKenna, M., \& Rizzo, E. (1999). Student's perceptions of the "learning" in servicelearning courses. Journal of Prevention of Intervention in the Community, 18(1/2), 111-123.

Morton, K. (1996). lssues related to integrating service-learning into the curriculum. In B. Jacoby \& Associates (Eds.), Service-learning in higher education: Concepts and practices (pp. 276-296). San Francisco, CA: Jossey-Bass.

Rhoads, R. A., \& Howard, J. (Eds.). (1998). Academic service learming: A pedagogy of action and reflection. San Francisco, CA: JosseyBass. 
Rice, K., \& Pollack, S. (2000). Developing a critical pedagogy of service learning: Preparing self-reflective, culturally aware, and responsive community participants. In C. O'Grady (Ed.), Integrating service learning and multicultural education in colleges and universities (pp. 115-134). Mahwah, NJ: Lawrence Erlbaum.

Rue, P. (1996). Administering successful service-learning programs. In B. Jacoby \& Associates (Eds.), Service-learning in higher education: Concepts and practices (pp. 246-275). San Francisco, CA: Jossey-Bass.

Stanton, T., Giles, D., \& Cruz, N. (1999). Service-learning: A movement's pioneers refect on its origins, practice and future. San Francisco, CA: Jossey-Bass.

Ward, K. (1998). Addressing academic culture: Service learning, organizations, and faculty work. In R. A. Rhoads \& J. Howard (Eds.), Academic service learning: $A$ pedagogy of action and reflection (pp. 73-80). San Francisco, CA: Jossey-Bass.

Weigert, K. (1998). Academic service learning: Its meaning and relevance. In R. A. Rhoads \& J. Howard (Eds.), Academic service learning: A pedagogy of action and reflection (pp. 3-10). San Francisco, CA: Jossey-Bass.

Westacort, B., \& Hegeman, C. (Eds.). (1996). Service learning in elder care: A resource manual. Albany, NY: Foundation for Long Term Care.

Zlorkowski, E. (1996). Foreword. In L. Adler-Kassner, R. Crooks, \& A. Watters (Eds.), Composition-Writing the community: Concepts and models for servicelearning in composition (pp. v-vii). Washingron, DC: American Association for Higher Education. 